\title{
A NEW TECHNIQUE OF INTUBATION FOR THE PREVENTION OF CONTRALATERAL INFECTION DURING LUNG SURGERY*
}

\section{LÉON LONGTIN, M.D., F.R.C.P.(C) *}

EsPECIALLY with "wet" ungs and in tuberculous patients, pulmonary surgery has raised the problem of contralateral contamination, a problem which still remains to be solved today. Whose problem is it? Surely not the patient's! The surgeons make the anaesthetists feel it is not the surgeon's problem, so we anaesthetists must try to solve it.

Drainage by position during operation has been tried and found helpful, but not entirely effective. Separate intubation of both main bronchi has been thought to be the solution of the problem, but the technical application of that principle has been hard to realize and does not seem to be properly realized yet.

For pulmonary surgery we have tried, at St. Joseph Sanatorium, Rosemont, Montreal, to build a separate air-tight circuit for each lung, using a technique we think is new.

\section{Description OF THE TUBES}

The technique consists in placing two separate tubes in the bronchial tree of the patient: one of these tubes, specially built for that purpose, is placed in the left main bronchus; the other one, an ordinary tracheal tube, is placed in the trachea as is usually done for tracheal intubation.

The specially built tube is thin-walled and a little hard to bend. It varies in size and length according to the dimensions of the bronchial tree of the patient, from 3 to $6 \mathrm{~mm}$. in diameter and 25 to $32 \mathrm{~cm}$. in length. At its distal extremity, about $2 \mathrm{~cm}$. from the end, there is a small curvature to the left, and the bevel is so cut that it naturally enters the left bronchus when arriving at the carina. Just below the bevel there is a small inflatable cuff which, when inflated, makes an air-tight circuit with the left lung. At 7 or $8 \mathrm{~cm}$. above the cuff, there is another inflatable cuff which, when the tube is in place, is supposed to be about $2 \mathrm{~cm}$. below the vocal cords.

The tracheal tubing has a diameter equal to the bronchial one, and is of proper length to reach $2 \mathrm{~cm}$. below the vocal cords. This tube has, at its distal end, two cufts-one near the bevel, and the other one just above the first. To make an air-tight circuit with the right lung, sometimes, we have had to inflate three cuffs, the upper one on the bronchial tube and the two others on the tracheal tube.

Each tube is connected with a separate anaesthetic machine, where different anaesthetic atmospheres may be employed at different pressures in the circuit, according to the requirements of the patient or of the surgeon, with different

\footnotetext{
Presented at the Annual Meeting, Canadian Medical Association, Toronto, Ont., June 20$24,1955$.

*L'Hôtel-Dieu, Montréal, and l'Université de Montréal.
} 
kinds of breathing systems: closed, semi-closed. Since the circuits are completely independent, they are just like two different patients.

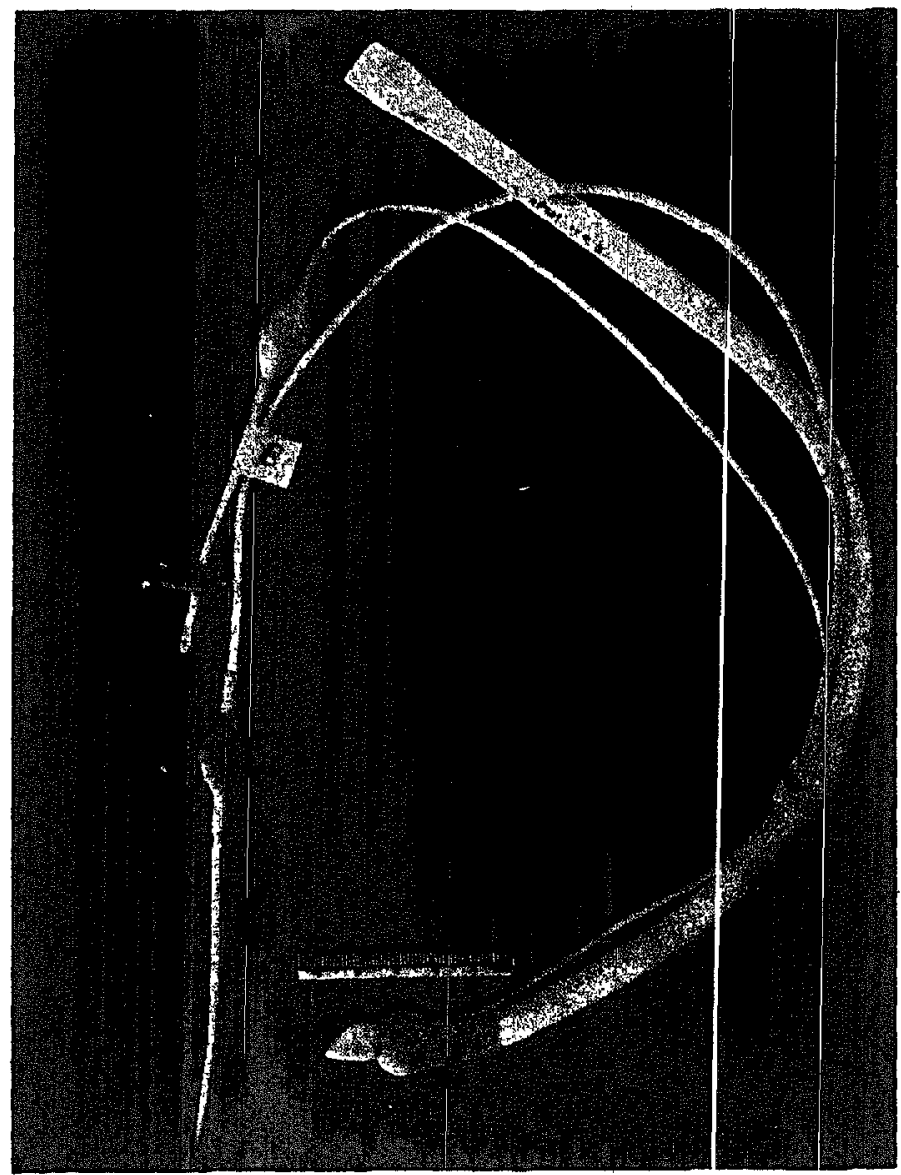

Frgure 1. Tube bronchique à bout incurvé à gauche, portant deux ballonnets dont l'un, le distal, ne gonfle que sur un centumètre de longueur pour établır un crrcuit étanche avec le poumon gauche.

\section{Description of Technique}

A few essential conditions are required to facilitate such intubation. The most important one is to have a deeply anaesthetized and well-relaxed patient. The deep anaesthesia prevents coughing during and after intubation and also prevents the displacement of the tube. Good relaxation, usually obtained by succinylcholine, helps in putting the tubes in place. In addition it is advisable to use well-lubricated tubes. This lubrication is usually done with soluble jelly containing anaesthetic agent but no vasopressor drug.

A second pair of hands may, sometimes, be helpful in checking the position of the tubes and the tightmess of the circuits.

It is advisable that bronchial intubation be performed on the left side, though it can be done more easily on the right side. When done on the right side, there is a greater risk of occlusion of the upper lobe bronchus by the tube and protection against infected secretions is not so completely effective.

During operation, suction can be done in one circuit without interfering with the other one, but it is advisable to have one catheter for each lung to prevent contamination of the healthy side by the catheter. 


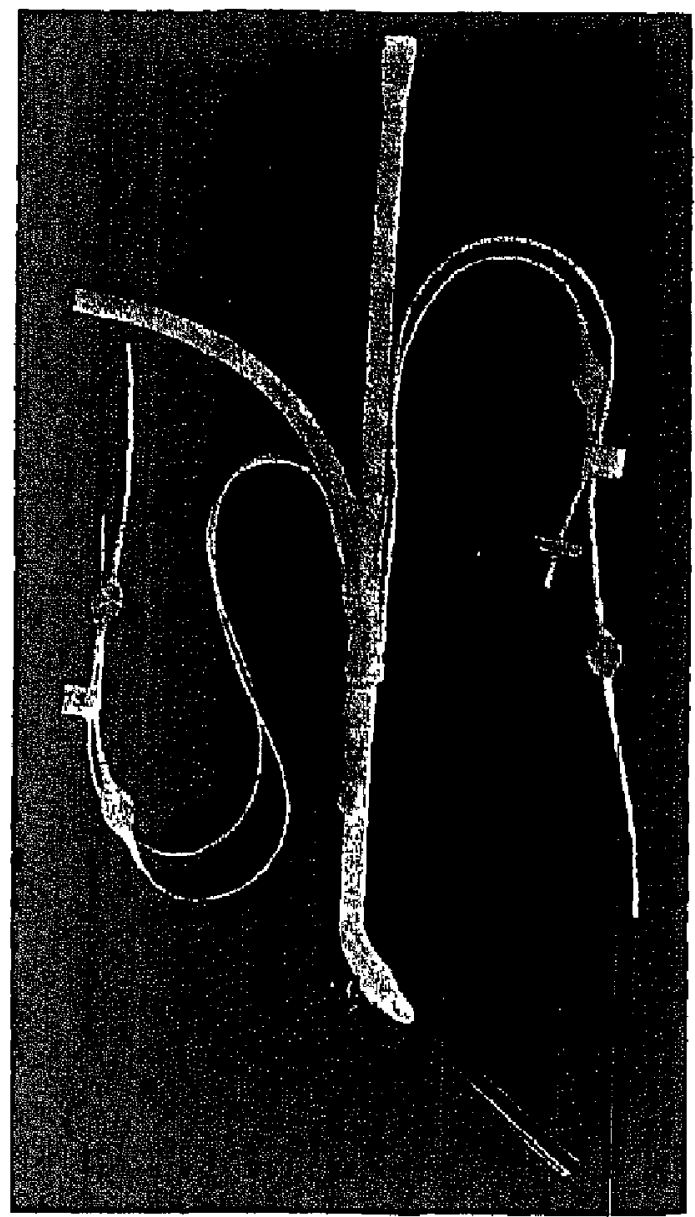

Figure 2 Les deux tubes, bronchique ct trachérl, en place dans un arbre bronchıque en verre Notez la position des ballonnets supérıeurs pour établı un circut étanche avec le poumon troit

\section{How to Clean the Bhonchlad Thee at Extubation}

In our opinion, extubation may be the very moment when contralateral contammation may occur For pioper cleaning of the bronchial tree at extubation when two tubes are used, we suggest the following techmque Suction must be done fixst through the tracheal tube When that part of the bronchial tree is will cleaned, the upper cuff of the bronchial tube and both cuffs of the tracheal tu je are deltated, then the tracheal tube is pulled out while the suction catheter remains in its lumen to aspirate the secretions gathered around the cuffs. After a good cleaning of the main left bronchus, the distal cuff of the bronchal tube is deflated and the same technique is followed to pull out the bronchial tube. that is, the sucton catheter is left in the lumen of the tube whle it is pulled out to complete the removal of all secretions

We feel that this technique permits a more adequate suction of infected secretions than does the double lumen tube As a matter of fact, suction catheters do not pass easily through double lumen tubes, and, when aspirating the right side, it is imporsible to clean the trachen before deflating the distal cuff in the 
left bronchus. When deflating that cuff in such circumstances, the infected secretions, gathered around the bronchial tubing between the two cuffs during the operation, may enter the left bronchus and spread the infection. At that moment the goal is missed.

Since January 1954, we have used the two-tube technique in about fifty cases of lung surgery. We feel it gives a quite complete security against contralateral contamination. It is easy to manage and to keep in place. It can be used even in deviated trachea. Suction is more easily and more adequately done.

Proper size and length of tubes are chosen for each patient, with the aim of avoiding excess of resistance and dead space.

The use of two machines with this technic ue and the maintenance of a steady positive pressure of $2-5 \mathrm{~mm}$. of mercury in the lung opposite to surgery prevents the shifting of the mediastinum and its consequent circulatory disturbances.

This technique is especially valuable in plastic surgery of the bronchi and in cases where both pleurae are opened; all cases where contralateral infection is feared during operation will be adequately protected in any position, with a technique which is easy for the anaesthetist to follow.

\section{RÉSUMÉ}

Cette technique consiste à placer dans la bronche gauche du malade un tube spécialement construit, de diamètre et de longueur appropriés pour chacun des malades; ce tube possède, à deux centimètres de son extrémité distale, une légère incurvation et un biseau taillé de telle sorte que, naturellement, le tube se place dans la bronche gauche quand il arrive à la carène. Ce tube bronchique porte deux ballonnets: l'un a son extrémité distale, près du biseau, mesurant environ un centimètre de longueur, ne dépassant pas la bronche souche gauche quand il est gonflé; l'autre, à 4 ou $5 \mathrm{~cm}$. au-dessus du premier, ballonnet détachable ordinaire, servant, si nécessaire seulement, à établir un circuit étanche dans le poumon droit à l'aide du tube intra-trachéal.

Quand le tube bronchique est en place dans la bronche gauche, on introduit dans la trachée un tube trachéal ordinaire, porteur, à son extrémité distale, de deux ballonnets: l'un est placé près du biseau du tube ef l'autre immédiatement au-dessus du premier. Pour obtenir un circuit étanche dans le poumon droit, il arrive qu'il soit nécessaire de gonfler ces deux ballonnets $t$ t le ballonnet supérieur sur le tube bronchique. Chacun de ces tubes est mis en communication avec une machine à anesthésie où peuvent être introduites des atmosphères anesthésiques différentes, à des pressions différentes, sous des formes différentes de circuits, tout comme s'il s'agissait de deux malades différents.

Pour mettre ces deux tubes en place et pour éviter que le malade les déplace en toussant après qu'ils sont installés, certaines précautions sont recommandables: il faut avoir un malade sous anesthésie profonde et bien relaché. Il est également souhaitable d'avoir un tube bien lubrifié.

A notre avis, la contamination contro-latérale peut survenir surtout au moment de l'extubation. Pour prévenir adéquatement cette contamination quand deux tubes sont employés, nous suggérons de procéder ainsi: à travers le tube trachéal, nettoyer la trachée et la bronche droite à maintes reprises et, après avoir dégonflé 
les deux ballonnets sur ce tube et le ballonnet supérieur sur le tube bron`hique, enlever le tube trachéal en laissant la sonde aspiratrice dans la lumière $c u$ tube trachéal pour continuer de débarrasser la trachée des sécrétions qui pourraient s'y trouver; ensuite, avec une sonde aspiratrice propre, nettoyer la bronche gauche à travers la lumière du tube bronchique et, après avoir dégonflé le ballonnet distal sur le tube bronchique, en laissant la sonde dans le tube bronchique comme pour le tube trachéal, retirer lentement le tube bronchique en aspirant, encore une fois, les sécrétions ou le sang venant du mognon bronchique qui pourraient se rencontrer dans la trachée,

L'usage d'un circuit différent pour chacun des poumons s'avère très utile au cours de la chirurgie pulmonaire ordinaire, mais cette technique est particulièrement appréciée pour la plastie des bronches et dans les cas où les deux plèvres sont ouvertes.

Il s'agit d'une technique d'intubation facile à appliquer et réalisant une protection adéquate contre l'infection , contro-latérale au cours de la chirurgie pulmonaire. 